WENDY BACON is an Associate Professor at the Australian Centre for Independent Journalism.

\section{Revelations that resist prevailing global lies and orthodoxies}

Tell Me No Lies: Investigative Journalism and Its Triumphs, edited by John Pilger. London: Jonathan Cape. 2004, 626 pp. ISBN 0224073796

A $\begin{aligned} & \text { s Columbia journalism pro } \\ & \text { fessor James Carey once wrote, }\end{aligned}$ while everyday reportage tells us the who, what, when and where of events, it usually fails to chart the deeper, less accessible level that lies below-the how and why. In Tell Me No Lies: Investigative Journalism and Its Triumphs, John Pilger presents an impressive collection of investigations, cover-ups and reports of crimes against humanity by writers who challenged these limitations.

In his introduction, Pilger, an Australian who has twice been named British journalist of the year, describes his contributors as those who

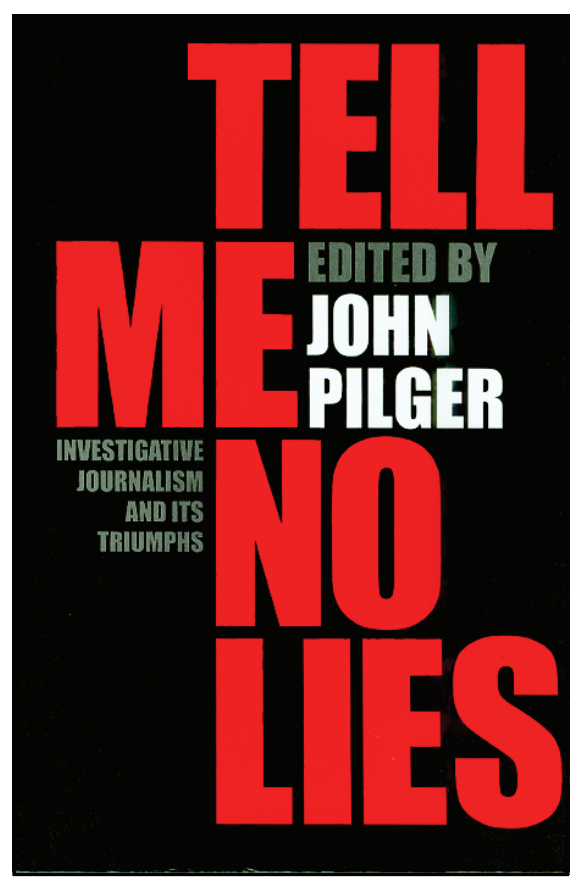

refuse to collaborate with 'secretive power' even if it means they are loathed. They 'push back screens, peer behind facades, lift rocks ... [and] alert their readers to vital, hidden truths'.

Their reports span a 60-year period from Martha Gellhorn's 1945 description of the skeletons of Dachau who 'sat in the sun and searched themselves for lice ... like nothing you will ever see if you are lucky'; to Robert Fisk's account IN 2004 from the Baghdad mortuary on a 'week's cull' of Iraqis whose relatives, waiting beside a lake of sewage, weep that 'no one cares'. 
For readers for whom the title suggests a collection of exposés, the breadth of Pilger's choices will be surprising. Alongside such famous stories as fellow Australian Philip Knightley's thalidomide scandal and Seymour Hersh's investigation of how US soldiers massacred hundreds of civilians at My Lai in 1968, there are reporters whose work simply, but no less importantly, bears witness to horrific events.

These include Russian journalist Anna Politkovskaya's report about the refugee mother who is alive physically but 'dead to the world' because contract soldiers in a 'dreadful and cynical atrocity' shot her children when she was driving them and her dead husband to his burial. Politkovskaya wrote:

You probably think I am writing all this to stir your pity ... But my notes have quite a different purpose, they are written for the future. They are the testimony of the innocent victims of the new Chechnyan war, which is why I record all the detail I can. (p. 411)

The anthology ends with a tribute to Edward Said, who died while this book was in preparation. Said saw himself as an investigator of the way that ideas and language can obscure the truth. He declares in this extract:
The language of suffering and concrete daily life has either been hijacked or it has been so perverted as, in my opinion, to be useless except as pure fiction deployed as a screen for the purpose of more killing and painstaking torture - slowly, fastidiously, inexorably. (p. 601)

While Said's statement reminds us that media have often hidden the truth as much as revealed it, this book is a testament to those who struggle to find words to penetrate his 'screen' to communicate to their readers the humanity of victims and the injustice they witness.

Australian Wilfred Burchett, the first journalist to visit Hiroshima after it was bombed, returned to a Tokyo press conference at which a highranking US official attempted to discredit his 'Warning to the World' report by denying there was any such thing as radiation caused by the atomic bomb.

Burchett's account ends with him saying that he observed fish in Hiroshima turning upside down as they entered a stretch of river and dying within seconds. 'I'm afraid you have fallen victim to Japanese propaganda,' said the official and sat down.

T. D. Allman was paying tribute to Burchett when he wrote that genuinely objective journalism 'not only gets the facts right, it gets the mean- 
ing of facts right. It is compelling not only today, but stands the test of time'. It is with these words that Pilger begins his introduction to this collection.

Journalists as 'outsiders' and the resistance reporters and sources meet in telling their stories is a theme throughout the book. For a year after US soldiers murdered 500 women, children and older men in My Lai, a discharged soldier tried to interest US media in the disturbing events he had witnessed. His story was finally taken up not by any of the 600 accredited reporters in Vietnam but by a young freelancer, the now famous Hersh, whom Pilger describes as 'an outsider who knows how to mine on the inside and is proud of his enemies'.

These days, radiation sickness and the My Lai massacre are accepted fact. Not so some more recent contributions that still lie in contested territory, often pushed to the margins of dominant media. Felicity Arbuthnot's account of increasing cancer among Iraqi children is a shocking reminder of an ongoing but buried story of the consequences of depleted uranium weaponry being used there.

This book will serve many purposes. It is a powerful demonstration that reporting at its best may involve resisting rather than catering to prevailing orthodoxies and that the line between journalism, history, literature and powerful social analysis is blurred.

As a single read, I found it overwhelming, but I will drop into and out of it in the future. There will be something memorable here for everyone interested in non-fiction. For my part, I cannot forget Fisk's horror when he realised that the barricade of muck he clambered upon in the Palestinian camp in Lebanon in 1982 was a shifting mass of massacred limbs and heads; Eric Schlosser's Salvadoran immigrant worker beheaded by an unsafe machine in a meat processing plant in Nebraska; and Pilger's shadows of children in the silence and devastation of Cambodia in 1979.

As I read, I made a list of books to read in 2005 by the authors here. This seemed as good a sign as any of a successful anthology. 